\title{
Validity and Reliability of Movement Learning Difficulties Instrument of Primary School Students
}

\author{
Didin Budiman*, Ricky Wibowo, Andi Suntoda \\ Physical Education Elementary \\ Universitas Pendidikan Indonesia \\ Bandung, Indonesia \\ *didinbudiman1974@upi.edu, ricky_wibowo@upi.edu, andisuntoda@upi.edu
}

\begin{abstract}
In the real practice of Physical Education learning, some teachers still have a lack of awareness in analysing student learning difficulties. The aim of this study was to determine the validity and reliability of movement learning difficulties instrument questionnaires in elementary school children. 228 student participated in the study aged $m ;=11,31(s d ; 0,76)$ years old. This program was a collaboration with physical education teachers to improve the identification instrument of elementary school student movement learning difficulties in PE based on the 2013 curriculum. Reliability was assessed with two consecutive measurements performed two weeks apart. Pearson product moment correlation coefficients were observed to measure of validity. The result show that the reliability of the instruments used in this study was acceptable. Based on the calculation process, $r$-count $r x y=0.81$ and $r=0.91$, while $r$-table of product moment shows that $n=16(\mathrm{dk}: \mathrm{n}-2=14)$ with $r 0.95$ is 0.532 , so $r$ count is greater than $\mathbf{r}$-table. This means that the questionnaire is reliable. The results of the correlation significance test show that the t-test is $\mathbf{5 . 5 5}$ while the t-table is at the real level of 0.05 and $\mathbf{~ d k}$ (14) is 1.76. This means that the t-test is greater than the t-table so that the correlation of the instrument is to have a significant reliability. In addition, validity for 34 test items there 2 items not valid due to is smaller than the value of $t$-table (1.9). As for the number of questions that can be used amounted to thirty two questionnaire.
\end{abstract}

Keywords: movement learning, reliability, validity

\section{INTRODUCTION}

Physical activity is the main media in the implementation of the physical education learning. Through physical activities, PE programs design to develop all aspects possessed by students. These include cognitive, affective, and psychomotor aspects. In the process of developing students' psychomotor abilities, the main activity is the transfer of task assignments from teacher to student. Specifically related to fundamental movement teaching materials $[1,2]$. This activity works well if there is a match between the fundamental movement material being taught, the learning objectives, and teaching methods with the level of students' movement abilities. And vice versa if there is no conformity, the learning environment is not conducive which in the end the learning objectives are not achieved.

What is meant by fundamental movement is a pattern of movement that is the basis for more complex dexterity of motion [3-5]. The movements include locomotor movements, non-locomotor movements, and manipulative movements [68]. These three forms of movement will develop well if they pass the stages of learning good motion as well.

Movement learning is a series of processes associated with training and experience that lead to relatively sedentary changes in one's ability to display skilled movements $[9,10]$. Therefore, fundamental movement learning for students must be able to be presented by PE teachers through systematic stages through the provision of practice and experience in order students gain changes in their fundamental movement improvement to be relatively settled. This can happen if every stage of learning movement always passes the verbal-cognitive stage, the stage of the motor and the stage of autonomous. Through this learning phase of the movement, the difficulty of mastering the basic movement tasks instructed by the teacher to students will be able to be minimized. The most important thing is that PE teachers always try to create a conducive learning environment.

As an anticipatory effort to avoid the occurrence of students' learning environment that is not conducive, PE teachers must truly understand the characteristics of the basic abilities of each student. All of this aims to enable the teacher to be able to present teaching materials that are in accordance with the needs, interests, and abilities of students by always sticking to the guidance of the PE curriculum. Actions that can be taken by the teacher include understanding the learning difficulties experienced by each student.

Understanding of learning difficulties will be owned by the Physical Education teacher if he has understood the concepts of learning and learning. For example, with regard to the concept of learning, the meaning of learning has two aspects; changes in behaviour and, changes in behaviour must be relatively permanent $[9,11]$. The behaviour in question is related to the whole domain owned by students, namely cognitive, psychomotor, and affective. For example in changes in the ability to kick the ball in fourth grade students. The ability to kick the ball will not quickly disappear when on other occasions students have to do it again. This means that the ability is inherent in students for a long time. In other words students do not quickly forget the ability to kick the ball they have even on further opportunities, the ability of students kicking a ball continues to increase until it becomes a high 
skill. As stated earlier, changes in behaviour that are sedentary as a result of motor learning cannot be directly obtained by students. There are systematic stages that must be passed first. In the concept of learning motion, the stages consist of three stages $[12,13]$.

Teaching physical education in elementary schools in general is still traditionally carried out, that is, the activities done by students are the same as those done by adults without modification [14-16]. For example the case when elementary school students. When new students first learn to play volleyball, then almost all the facilities and infrastructure they use are identical in size to the facilities and infrastructure used by adults. If this still happens then students are faced with a formidable challenge in mastering the motor tasks of playing volleyball. So that only learning difficulties will be overcome. For this reason it is necessary to be a study material so that student learning difficulties can be minimized so that the effectiveness of learning will be more easily achieved.

Factors that influence the effectiveness of learning behaviour are drives, attention and knowing the target, response, reinforcement. These four aspects can be grown by the existence of stimulus from the PE teacher to students when presenting learning [14]. For example from the choice of teaching methods and approaches implemented by the teacher during the Physical Education learning process. If there is no match between the stimulus from the teacher and the response shown by the students, this means that there has been an indication of difficulties in learning the movements of the students.

If any learning difficulties occur, the background will be sourced from the components (methods, materials, objectives, evaluation) that influence the ongoing teaching and learning process itself. While the variables that influence the teaching and learning process namely: stimulus or learning variables, organismic variables, and response variables [17].

The stimulus variable is the first factor that causes interaction between the teaching and learning process between the teacher and students, because the first and dominant teacher gives stimulation to students to respond to it which is manifested in the form of learning behaviour. Learning variables on stimulus factors are generally divided into two factors. The first factor is the learning experience variable and the second factor is the environmental context variable. Learning experience variable regarding teaching methods and teaching assignments, while the environmental variable is related to the learning climate which depends on factors of place and learning space, time, facilities, and social relations.

These two factors are presented by PE teachers. These two factors also can be the reason for the success of students mastering teaching materials or vice versa students are not able to master teaching materials. Instead of achieving the goal of learning motion, even during the learning process students even experience learning difficulties. For this reason, it is necessary to analyse the influence of each factor that can be a cause of learning difficulties for fundamental movement in students, especially in the two stimulus variables consisting of learning experiences and environmental factors.

\section{METHOD}

\section{A. Participant and Setting}

Before taking data, the authors gathered physical education teachers to discuss the identification of elementary school students' learning difficulties in the form of focus group discussions. Physical education teachers numbered 30 people involved in making instruments that were initiated by researchers. As for the number of fair questions made based on the results of the FGD are 34 questions. The questionnaire that contained the questions was then distributed to physical education teachers. The physical education teacher accompanied by the researcher took the questionnaire data accompanied by the research team. After the Physical Education teacher took questionnaire data to each of their students, the questionnaire was collected to the research team for analysis. The questionnaire collected from students in the city of Bandung totalled 228 questionnaires. The sample characteristics amounted to 117 male students and 111 female students. With an age range between 9-10 years. The questionnaire grid is presented in table 1 .

\section{TABLE I. QUESTIONNAIRE}

\begin{tabular}{|c|c|c|c|}
\hline Variable & Sub-variable & Indicator & Number \\
\hline \multirow[t]{12}{*}{$\begin{array}{l}\text { Stimulus } \\
\text { (Learning) } \\
\text { Variables }\end{array}$} & $\begin{array}{l}\text { Learning } \\
\text { experiences } \\
\text { variables } \\
\end{array}$ & & \\
\hline & \multirow[t]{4}{*}{$\begin{array}{l}\text { Method } \\
\text { variables }\end{array}$} & $\begin{array}{l}\text { High and Low } \\
\text { Motivation of Students } \\
\text { To Learn }\end{array}$ & 4 \\
\hline & & $\begin{array}{l}\text { Intensive or Not Teacher } \\
\text { Guidance }\end{array}$ & 6 \\
\hline & & $\begin{array}{l}\text { Opportunities to Train } \\
\text { Or Practice }\end{array}$ & 10 \\
\hline & & $\begin{array}{lr}\text { Efforts } & \text { And } \\
\text { Opportunities } & \text { to } \\
\text { Strengthen } & \text { Learning } \\
\text { Outcomes } & \\
\text { (Reinforcement) } & \end{array}$ & 9 \\
\hline & \multirow[t]{3}{*}{$\begin{array}{l}\text { Task } \\
\text { Variables }\end{array}$} & $\begin{array}{l}\text { Interesting or Not What } \\
\text { Should Be Learned }\end{array}$ & 1 \\
\hline & & $\begin{array}{l}\text { Meaningful } \\
\text { (Meaningfulness) What } \\
\text { is Learned And Done }\end{array}$ & 5 \\
\hline & & $\begin{array}{l}\text { Appropriate or Not } \\
\text { (Appropriatness), The } \\
\text { Length or Breadth And } \\
\text { Level of Difficulty What } \\
\text { Must be Learned and } \\
\text { Done }\end{array}$ & 11 \\
\hline & \multirow{4}{*}{$\begin{array}{l}\text { Environmenta } \\
1 \text { variables }\end{array}$} & There is Adequate Space & 7 \\
\hline & & $\begin{array}{l}\text { Enough Time And } \\
\text { Appropriate Use of Time } \\
\text { For Learning }\end{array}$ & 2 \\
\hline & & $\begin{array}{l}\text { Adequate Learning } \\
\text { Facilities are Available }\end{array}$ & 8 \\
\hline & & $\begin{array}{l}\text { Harmonious or Not } \\
\text { Student Relations Both } \\
\text { At School, At Home } \\
\text { And In The Wider } \\
\text { Community }\end{array}$ & 3 \\
\hline
\end{tabular}




\section{RESULT}

From the table 2 it is show that from 34 items there are 2 (two) items that are not valid, namely no. 12 and 24 because the value of t-count (1.5 and 1.4) is smaller than the value of $t-$ table (1.9). Based on the calculation process, $r$-count $r x y=$ 0.81 and rii $=0.91$, while $r$-table of product moment shows that $\mathrm{n}=16(\mathrm{dk}: \mathrm{n}-2=14)$ with the price of $\mathrm{r} 0.95$ is 0.532 , so $\mathrm{r}$ count is greater than r-table. This means that the questionnaire is reliable. The results of the correlation significance test show that the t-test is 5.55 while the t-table is at the real level of 0.05 and $\mathrm{dk}(14)$ is 1.76 . This means that $\mathrm{t}$-count is greater than $\mathrm{t}-$ table so that the correlation of instruments is to have a significant reliability.

TABLE II. VALIDITY TEST

\begin{tabular}{|l|l|l|l|l|l|}
\hline Number & $\begin{array}{c}\text { t- } \\
\text { count }\end{array}$ & question & \multicolumn{1}{|c|}{$\begin{array}{c}\text { number } \\
\text { count }\end{array}$} & \\
\hline 1 & 3,3 & valid & 18 & 2,4 & valid \\
\hline 2 & 3,1 & valid & 19 & 2,7 & valid \\
\hline 3 & 2,8 & valid & 20 & 2,2 & valid \\
\hline 4 & 2,9 & valid & 21 & 2,3 & valid \\
\hline 5 & 2,2 & valid & 22 & 2,5 & valid \\
\hline 6 & 3,7 & valid & 23 & 3,5 & valid \\
\hline 7 & 2,3 & valid & 24 & 1,4 & Not \\
& & & & 2,5 & valid \\
\hline 8 & 2,7 & valid & 25 & 2,6 & valid \\
\hline 9 & 2,5 & valid & 26 & 2,3 & valid \\
\hline 10 & 2,2 & valid & 27 & 2,1 & valid \\
\hline 11 & 2,4 & valid & 28 & 2,1 & valid \\
\hline 12 & 1,5 & Not & 29 & 2,5 & valid \\
\hline 13 & 5,2 & valid & 30 & 2,7 & valid \\
\hline 14 & 2,5 & valid & 31 & 2,6 & valid \\
\hline 15 & 2,2 & valid & 32 & 2,5 & valid \\
\hline 16 & 2,2 & valid & 33 & valid \\
\hline 17 & 2,6 & valid & 34 & \\
\hline
\end{tabular}

\section{CONCLUSION}

The Instrument of learning difficulties for elementary school students can be used by teachers to identify learning difficulties for elementary school students to help students achieve the learning goals set by the teacher in accordance with curriculum development in Indonesia. As for the number of questions that can be used amounted to thirty two questionnaire.

\section{ACKNOWLEDGMENT}

The authors would like to thank the participants who gave their time to the study. We would also like to thank the schools who helped facilitate the research. Lastly, thanks to LPPM UPI for the funding.

\section{REFERENCES}

[1] R. Wibowo, E. Nugraha and K. Sultoni, "Fundamental Movement Skills and Moods as Predictors of Games Performance in Primary School Students," ACTIVE: Journal of Physical Education, Sport, Health and Recreation, vol. 7(1), pp. 44-49, 2018.

[2] N. Lander, N. Eather, P.J. Morgan, J. Salmon and L.M. Barnett, "Characteristics of teacher training in school-based physical education interventions to improve fundamental movement skills and/or physical activity: A systematic review," Sports Medicine, vol. 47(1), pp. 135-161, 2017.

[3] K. Sultoni, A. Suherman and R. Wibowo, "Increasing Gross Motor Skill Through Fundamental Skill Development Program," ACTIVE: Journal of Physical Education, Sport, Health and Recreation, vol. 7(1), pp. 3943, 2018.

[4] D.R. Lubans, P.J. Morgan, D.P. Cliff, L.M. Barnett and A.D. Okely, "Fundamental movement skills in children and adolescents," Sports medicine, vol. 40(12), pp. 1019-1035, 2010.

[5] R.A. Jones, A. Riethmuller, K. Hesketh, J. Trezise, M. Batterham and A.D. Okely, "Promoting fundamental movement skill development and physical activity in early childhood settings: a cluster randomized controlled trial," Pediatric exercise science, vol. 23(4), pp. 600-615, 2011.

[6] M. Fadilah and R. Wibowo, "Kontribusi Keterampilan Gerak Fundamental Terhadap Keterampilan Bermain Small-Sided Handball Games," Jurnal Pendidikan Jasmani dan Olahraga, vol. 3(1), pp. 60-68, 2018.

[7] V. Derri, A. Tsapakidou, E. Zachopoulou and E. Kioumourtzoglou, "Effect of a music and movement programme on development of locomotor skills by children 4 to 6 years of age," European Journal of Physical Education, vol. 6(1), pp. 16-25, 2001.

[8] M.L. Leppo, D. Davis and B. Crim, "The basics of exercising the mind and body," Childhood Education, vol. 76(3), pp. 142-147, 2000.

[9] Amung Ma'mun dan Agus Mahendra, Teori Belajar dan Pembelajaran Motorik. Bandung: IKIP Bandung Press, 1998.

[10] L.M. Gagen and N. Getchell, "Using 'constraints' to design developmentally appropriate movement activities for early childhood education," Early Childhood Education Journal, vol. 34(3), pp. 227-232, 2006.

[11] D.M. McInerney, R.W.Y. Cheng, M.M.C. Mok and A.K.H. Lam, "Academic self-concept and learning strategies: Direction of effect on student academic achievement," Journal of Advanced Academics, vol. 23(3), pp. 249-269, 2012.

[12] Richard A. Schmidt, Motor Learning and Performanca From Principles to Practice. Illionis: Human Kinetics Books, 1991.

[13] J. Park and S. Han, "Using deductive reasoning to promote the change of students' conceptions about force and motion," International Journal of Science Education, vol. 24(6), pp. 593-609, 2002.

[14] Toho Cholik dan Rusli Lutan, Pendidikan Jasmani dan Kesehatan, Jakarta: Depdiknas Dirjen Dikti Bagian Proyek Pengembangan Pendidikan Guru Sekolah Dasar, 1996.

[15] K.C. Graber, L.F. Locke, D. Lambdin and M.A. Solmon, "The landscape of elementary school physical education," The Elementary School Journal, vol. 108(3), pp. 151-159, 2008.

[16] R. Mersh and S.J. Fairclough, "Physical activity, lesson context and teacher behaviours within the revised English National Curriculum for Physical Education: A case study of one school," European Physical Education Review, vol. 16(1), pp. 29-45, 2010.

[17] Abin Syamsuddin Makmun, Psikologi Pendidikan, Bandung: PT Remaja Rosdakarya, 2004. 